\title{
PROPOSAL FOR DETERMING THE SCALE OF RENOVATION NEEDS OF RESIDENTIAL BUILDINGS
}

\author{
Beata NOWOGOŃSKA ${ }^{1}$ \\ University of Zielona Gora, Zielona Góra, Poland
}

\begin{abstract}
The scope of renovation works depends, above all, on the state in which a historical site has been preserved. All actions ought to be preceded by an assessment of the technical condition of the buildings. The article presents a method for determining the scale of needs for renovating existing buildings constructed in traditional technology. The established planning decision criteria, determined by measures of decision criteria and the weights of these criteria comprise output data for establishing a matrix of indicators for the order in which works ought to be carried out. Results of using it on inhabited residential buildings located in Gorzów Wielkopolski have also been presented.
\end{abstract}

Keywords: technical condition, degree of wear, renovation needs

\section{INTRODUCTION}

Maintaining residential buildings in adequate technical condition requires, above all, carrying out renovation works. However, these are often neglected and, with the passing of time, repair needs continue to grow [2, 3, 4, 9]. For larger groups of buildings it can be stated that the buildings and their individual components display different degrees of damage. The accurate determination of the technical condition of the building and reasons behind the damage make it possible to determine repair needs. However, due to restricted financial sources, the problem for the decision-maker is always the dilemma regarding the choice of the element subjected to renovation. The proposed method for determining

${ }^{1}$ Corresponding author: University of Zielona Gora, Faculty of Building, Architecture and Environmental Engineering, Z. Szafrana st 1, 65-516 Zielona Góra, Poland, e-mail: b.nowogonska@ib.uz.zgora.pl, tel. +48683282290 
the scale of renovation needs for existing residential buildings displaying varying degrees of wear can prove helpful in making such a decision.

\section{STUDY MATERIAL}

The studies were carried out on 30 selected residential buildings constructed using traditional technology. These town houses were built in the 30's of the $19^{\text {th }}$ century, and are located within the city of Gorzów Wielkopolski. The buildings covered by the analysis are characterized by similar solutions in terms of their construction and materials used. All of them are two storeys high with full basements, in compact development, and designed on an extended rectangular layout. The walls of the analyzed buildings were made of full brick, the floors over the basements are brick infill floors, with the remaining floors constructed on wooden beams construction; the stairs and roof trusses are wooden, with a collar beam roof structure, and roof covering is comprised of plain type pantile or roofing felt. The manager of all of the analyzed buildings is the Housing Management Department in Gorzów Wielkopolski. In all of the analyzed buildings, periodical inspections of the technical conditions were carried out, and the percentage of wear for individual building components established [7] (Table 1).

The presented results of the evaluation of the technical conditions indicate an average technical condition of the analyzed buildings. Average values of the degree of wear for all elements are higher than $25 \%$. The situation is also worrisome because of the maximum values of wear, amounting to $80 \%$, occurring in building components. However, the high values of variation coefficients indicate significant differences in the technical condition of the analyzed buildings. For a few of the building components, the variation coefficients were approximately $30 \%$. The obtained results indicate that the buildings are diverse in terms of their degree of wear. The differences in the technical condition of the analyzed buildings results from renovation works carried out within the last years on certain elements.

\section{ASSUMPTIONS OF THE METHOD FOR ASSESSING THE SCALE OF RENOVATION NEEDS}

The proposed method, referred to as the indicator method, for assessing the scale of renovation needs in residential buildings is comprised of the following course of action:

1. determining criteria accounting for factors influencing the order of repairs;

2. determining weight coefficients for the individual criteria;

3. establishing a set of buildings subjected to analysis; 
4. determining numerical measures of the criteria;

5. determining the mathematical equation leading to providing the order or renovation works;

6. providing indicators determining the choice of the order of elements.

Table 1. Average values of the degree of wear of individual building components

\begin{tabular}{|c|l|c|c|c|c|c|}
\hline No. & $\begin{array}{c}\text { Name of building } \\
\text { component }\end{array}$ & $\begin{array}{c}\text { Average } \\
\text { value }\end{array}$ & Min. & Max. & $\begin{array}{c}\text { Standard } \\
\text { Deviation }\end{array}$ & $\begin{array}{c}\text { Coefficient of } \\
\text { Variation }\end{array}$ \\
\hline 1. & Load-bearing walls & 32.2 & 30 & 50 & 8.8 & $14.20 \%$ \\
\hline 2. & Floor structure & 42.2 & 40 & 80 & 12.4 & $22.16 \%$ \\
\hline 3. & Stairs and landings & 44.6 & 40 & 80 & 16.2 & $24.18 \%$ \\
\hline 4. & Roof structure & 44.2 & 40 & 50 & 16.4 & $24.66 \%$ \\
\hline 5. & Roof covering & 46.4 & 20 & 60 & 28.4 & $26.42 \%$ \\
\hline 6. & $\begin{array}{l}\text { Rainwater pipes } \\
\text { and gutters }\end{array}$ & 54.2 & 5 & 80 & 26.2 & $28.98 \%$ \\
\hline 7. & $\begin{array}{l}\text { Floors and floor } \\
\text { surfaces covers }\end{array}$ & 24.4 & 5 & 80 & 12.2 & $10.84 \%$ \\
\hline 8. & Windows & 32.4 & 15 & 80 & 14.6 & $22.02 \%$ \\
\hline 9. & Doors & 44.8 & 15 & 70 & 12.8 & $21.68 \%$ \\
\hline 10. & Plumbing & 54.4 & 10 & 80 & 12.4 & $28.22 \%$ \\
\hline 11. & Sewerage & 56.4 & 10 & 70 & 20.8 & $28.26 \%$ \\
\hline 12. & Heating & 56.8 & 10 & 70 & 24.2 & $32.84 \%$ \\
\hline 13. & Outside plasters & 42.2 & 10 & 60 & 14.8 & $20.26 \%$ \\
\hline 14. & Inside plasters & 44.4 & 10 & 80 & 16.8 & $28.42 \%$ \\
\hline
\end{tabular}

The following criteria were accepted in the method: the degree of wear of a building component; the building structure; the life expectancy of the component; the influence of damage to the component on other components; the interdependence of renovating the component with the renovation of another component; the location of the building; the cultural value of the building.

The criterion of the degree of wear of individual building components is dependent on the percentage value of element wear, which is established during the evaluation of the technical condition of the building. The criterion of structure calls for dividing the building into construction, covering, furnishing and finishing elements. The criterion of life expectancy accounts for the different processes of building component wear due to their various life expectancies. The influence of damage on other components [5] was determined on the basis of the influence of the worn component on damage to other building components. The criteria applied in the indicator method are, however, only the selected main premises indicating the order of renovation works. Many other assumptions used to program renovation works exist, e.g.: the interdependence of carrying out building renovations in compact development, the type of 
building materials and construction technology used, and criteria connected with the modernization of buildings.

The weights of criteria coincide with decision criteria. These weights were established on the basis of consultations with people connected with the renovation of residential buildings: real estate managers, university researchers, property valuers, conservators, and employees of architectural studios and remodeling companies. It is, however, believed that establishing the weights of decision criteria is a very complex problem and would require confirmation of the accepted weights in the future. A wide-reaching, nation-wide survey among those interested in the scope of selecting criteria for planning revitalization and establishing the weights of those criteria could, for example, be used for this purpose.

The established decision criteria for planning renovation works $\mathrm{p}_{1}, \mathrm{p}_{2}, . ., \mathrm{p}_{7}$ determined by measures of decision criteria $\mathrm{z}_{\mathrm{i}, \mathrm{j}}, \mathrm{f}_{\mathrm{i}, \mathrm{j}}, \mathrm{t}_{\mathrm{i}, \mathrm{j}}, \mathrm{b}_{\mathrm{i}, \mathrm{j}}, \mathrm{r}_{\mathrm{i}, \mathrm{j}}, \mathrm{l}_{\mathrm{i}, \mathrm{j}}, \mathrm{h}_{\mathrm{i}, \mathrm{j}}$ as well as the weights of those criteria $\mathrm{w}_{1}, \mathrm{w}_{2}, \ldots, \mathrm{w}_{7}$ serve as output data for determining matrices of renovation work order indicators $\mathrm{k}_{\mathrm{i}, \mathrm{j}}[6]$.

\section{PROPOSAL OF A METHOD OF DETERMINING THE SCALE OF RENOVATION NEEDS}

The order in which renovation works ought to be carried out can be established upon arranging the order indicators $\mathrm{k}_{\mathrm{i}, \mathrm{j}}$. Order indicators for $\mathrm{n}$ components in the $\mathrm{j}$-th building can be obtained solving the matric equation:

$$
\begin{aligned}
& \mathrm{K}_{\mathrm{j}}=\mathrm{D}_{\mathrm{j}} \times \mathrm{W}_{\mathrm{p}} \\
& {\left[\mathrm{k}_{\mathrm{ip}, \mathrm{j}}\right]_{\mathrm{mx} 1}=\left[\mathrm{d}_{\mathrm{ip}, \mathrm{j}}\right]_{\mathrm{mxu}} \quad \mathrm{x} \quad\left[\mathrm{w}_{\mathrm{p}}\right]_{\mathrm{ux} 1}}
\end{aligned}
$$

where:

$\mathrm{K}_{\mathrm{j}},\left[\mathrm{k}_{\mathrm{ip}, \mathrm{j}}\right]_{\mathrm{mx} 1} \quad$ - matrix of indicators determining the order of renovation works on components of the $\mathrm{j}$-th building,

$D_{j},\left[d_{i p, j}\right]_{m x u}$ - matrix of measures of criteria for components of the $j$-th building,

$\mathrm{W}_{\mathrm{p}},\left[\mathrm{w}_{\mathrm{p}}\right]_{\mathrm{ux} 1}$ - matrix of criteria weights,

i - number of building components, $\mathrm{i}=1,2, \ldots, \mathrm{m}$,

j - number of building, $\mathrm{j}=1,2, \ldots, \mathrm{n}$,

$\mathrm{p} \quad-$ number of criterion, $\mathrm{p}=1,2, \ldots, \mathrm{u}$.

The task is based on solving the matrix equation. The product of the numerical measures of criteria and the weights of these criteria is appointed to each analyzed component in the given building which was accounted for in the study. Number values which are the result of the study are an indicator of the order of carrying out renovation works $-\mathrm{k}_{\mathrm{i}, \mathrm{j}}$. The higher the indicator, the more necessary 
the renovation of the $\mathrm{i}$-th component in the $\mathrm{j}$-th building. The indicator does not, however, imply any physical amount of renovated components, but is merely used to arrange the building components in regards to the necessity of carrying out renovation works.

Applying the basic principles of operations on matrices, we can obtain a mathematical image of the $\mathrm{i}$-th element in the $\mathrm{j}$-th building:

$$
k_{i, j}=z_{i, j} * w_{z}+f_{i, j} * w_{f}+t_{i, j} * w_{t}+b_{i, j} * w_{b}+r_{i, j} * w_{r}+l_{i, j} * w_{l}+h_{i, j} * w_{h}
$$

The result of the equation (2) is an indicator of the order for a specific building component in the given building.

An interesting order of renovation works can be obtained by comparing the order indicators of components which, according to preliminary selection, were qualified for repair works.

For a larger set of buildings, the result will be a set of matrices in an amount corresponding to the number of buildings. The specified expressions of matrices give the possibility of ordering the analyzed buildings and their components in any number of buildings, and determining the relation of the order for any two buildings and their components in regard to each other.

In planning revitalization works, one can use the indicator method to prepare a schedule of repair works. This method does not, however, make it possible to determine the date of renovating an analyzed building and its components, as this depends on the funds available to the building manager for renovation purposes, as well as the costs of renovating the individual building components.

What is more, in order to establish the scale of renovation needs of building components, the obtained numerical values $\mathrm{k}_{\mathrm{i}, \mathrm{j}}$ grouped into sets determine:

- components for which renovation is indisputably required,

- components for which renovation works are necessary,

- components for which renovation works are recommended,

- components for which renovation is not currently required.

\section{SCALE OF RENOVATION NEEDS OF ANALYZED BUILDINGS}

The proposed indicator method was applied for planning revitalization works in Gorzów Wielkopolski. Accordingly to the assumptions of the indicator method, calculations were carried out on data regarding the technical condition of the 30 buildings subjected to analysis. The obtained results, as indicators of the order of carrying out renovation works on individual components of all of the analyzed buildings, upon being arranged in order of decreasing value, indicate 
the order in which renovation works on all building components should be carried out. They also show the scale of the needs for revitalization works.

The obtained results make it possible to state that, among all building components, the highest values of order indicators were obtained, on average, for the roof truss structure, roof covering, and rainwater pipes and gutters, for which the average values are greater than 0.08 . These elements should be the first to be subjected to renovation works.

In order to establish the scale of the renovation needs of elements in buildings, four categories of components were assumed:

- Components for which renovation is indisputably required, with values of order indicators higher than 0.068 (corresponding to bad technical condition),

- Components for which renovation works are necessary, with values of order indicators in the range of values from 0.051 to 0.068 ,

- Components for which renovation works are recommended, with values of order indicators in the range of values from 0.031 to 0.051 ,

- Components for which renovation is not currently required, with values of order indicators under 0.031 .

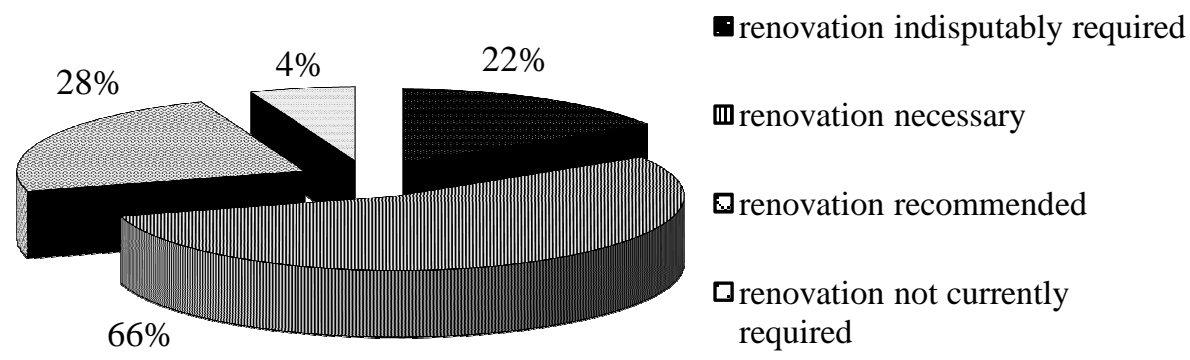

Fig. 1. Scale of needs for renovation work on building components (own elaboration)

The first two categories include building components for which the degree of wear is higher than 50\%; among them, renovation works can be additionally indisputably recommended due to the cultural value of the building or its location. The group of components for which renovation is recommended includes those whose degree of wear is lower than $50 \%$, however, due to their location and cultural conditions of the building, repair work on its components ought to be carried out earlier than on those in the fourth category.

Accepting a division of building components into four categories, one can assess the scale of the renovation needs of a group of buildings subjected to analysis. 
Results presented in Fig. 1 prove the validity of the negative assessment of the housing situation in Poland [1, 8]. Among the 14 components of 30 buildings covered by the analysis (a total of 420 components), repair work is not currently required for only $4 \%$ of the components (most often the outside plasters), whereas the remaining $96 \%$ ought to be subjected to renovation works. For $22 \%$ of the components, renovation is indisputably necessary, for $66 \%$ necessary, and for $28 \%$ comoponents - recommended.

\section{CONCLUSIONS}

The proposed model for determining the scale of needs for renovation works on buildings makes it possible to order the analyzed building components in terms of the necessity of carrying out renovation works, as well as determine the relationship of the order of any two buildings in regards to each other. This method can be applied to planning renovations on a single building as well as on a larger group of buildings.

\section{REFERENCES}

1. Biliński T.: Brak szans polepszenia sytuacji mieszkaniowej w Polsce. Kwartalnik Naukowy „Problemy rozwoju budownictwa” 2/2001.

2. Brunarski L., Runkiewicz L.: Diagnostyka obiektów budowlanych. Materiały konf. 56 Konferencji Naukowej KILiW PAN i PZiTB Krynica 2010.

3. Kasprowicz T.: Eksploatacja obiektów budowlanych. Materiały konf. 51 Konferencji Naukowej KILiW PAN i KN PZITB - Krynica 2005.

4. Knyziak P.: Analysis of the technical state for large-panel residential buildings using artificial neural networks, 17th International Conference On The Application Of Computer Science And Mathematics In Architecture And Civil Engineering, Weimar, Germany, 12 14.06.2006.

5. Nowogońska B.: Interdependence of building elements in the analysis of repair. W: Civil and Environmental Engineering Reports - 2012 No. 9, s. 83-91.

6. Nowogońska B.: The assessment of building repair needs with the use of an indicator method International Journal of Civil Engineering . 2015, Vol. 4, no. 2, s. 35 - 44.

7. Protokoły okresowej kontroli budynków mieszkalnych zarządzanych przez Zakład Gospodarki Mieszkaniowej w Gorzowie Wlkp.

8. Runkiewicz L.: Zagrożenia obiektów budowlanych a potrzeby remontów $i$ wzmocnień. [w:] Praca zbiorowa Materiały konferencyjne X Jubileuszowej 
Konferencji Naukowo-Technicznej nt. „Problemy remontowe $w$ budownictwie ogólnym $i$ obiektach zabytkowych" Wydawnictwo Politechniki Wrocławskiej, Wrocław 2002.

9. Skarzyński A.: Próba ogólnej systematyki sytuacji kryzysowych oraz wybranych towarzyszacych im działań techniczno-organizacyjnych. Materiały konferencyjne XI Konferencji Inżynierii Wojskowej nt. „Inżynieria i Zarządzanie w Sytuacjach Kryzysowych”, Warszawa 2000.

\section{PROPOZYCJA OKREŚLANIA SKALI POTRZEB RENOWACJI BUDYNKÓW MIESZKALNYCH}

Streszczenie

Zakres zadań renowacyjnych zależy przede wszystkim od stanu zachowania zabytkowego miejsca. Wszelkie działania powinny być poprzedzone oceną stanu technicznego obiektów. W artykule została przedstawiona metoda określania rozmiaru potrzeb renowacji istniejących budynków, wykonanych w technologii tradycyjnej. Ustalone kryteria decyzyjne planowania prac renowacyjnych określone przez mierniki kryteriów decyzyjnych oraz wagi tych kryteriów stanowią dane wyjściowe do wyznaczania macierzy wskaźników kolejności wykonywania prac. W metodzie przyjęto następujące kryteria: stopień zużycia elementu budynku; struktura budynku; okres trwałości elementu; wpływ zniszczenia elementu na inne elementy; współzależność remontu elementu związana z remontem innego; lokalizacja obiektu; wartość kulturowa obiektu. Zaprezentowane zostały także wyniki wykorzystani zaproponowanej metody dla aktualnie użytkowanych budynków mieszkalnych zlokalizowanych w Gorzowie Wlkp.

Słowa kluczowe: stan techniczny, stopień zużycia, potrzeby remontowe

Editor received the manuscript: 05.02.2015 